\title{
Osteoarthrosis of The Knee: Threat To Quality Of Life
}

\author{
Leonardo Domínguez Plain ${ }^{1}$, Claribel Plain Pazos ${ }^{2 *}$, Sergio Morales Piñeiro ${ }^{3}$, Juan Carlos Cedré \\ González ${ }^{4}$ and Anisbel Pérez de Alejo Plain ${ }^{5}$ \\ ${ }^{1} 2^{\text {nd }}$ year Orthopedic Resident Teaching General Teaching Hospital "Mártires del 9 de Abril", Sagua la Grande, Villa Clara, Cuba
}

${ }^{2}$ Specialist of I and II Degree in Comprehensive General Medicine, Assistant Professor, Faculty of Medical Sciences of Sagua la Grande, Villa Clara, Cuba

${ }^{3}$ Specialist of I and II Degree in Orthopedic, Assistant Professor, Teaching General Teaching Hospital "Mártires del 9 de Abril", Sagua la Grande, Villa Clara, Cuba

${ }^{4}$ Specialist of I Degree in Orthopedic, Assistant Professor, Teaching General Teaching Hospital "Mártires del 9 de Abril”, Sagua la Grande, Villa Clara, Cuba

${ }^{5} 3^{\text {rd }}$ Year Student of Medicine, Medical Faculty of Medical Sciences of Sagua la Grande, Villa Clara, Cuba

*Corresponding author: Claribel Plain Pazos, Specialist of I and II Degree in Comprehensive General Medicine, Assistant Professor, Faculty of Medical Sciences of Sagua la Grande, Villa Clara, Cuba

\begin{tabular}{|c|c|}
\hline ARTICLE INFO & Abstract \\
\hline Received: 慧 March 18, 2020 & Citation: Leonardo Domínguez P, Claribel Plain P, Sergio Morales P, Juan Carlos Cedré G, \\
\hline Published: 蔧 May 15, 2020 & $\begin{array}{l}\text { Anisbel Pérez de Alejo P. Osteoarthrosis Of The Knee: Threat To Quality Of Life. Biomed } \\
\text { J Sci \& Tech Res 27(4)-2020. BJSTR. MS.ID.004543. }\end{array}$ \\
\hline
\end{tabular}

\section{Short Communication}

Osteoarthrosis of the knee is a chronic disease with a high prevalence worldwide. As populations age, the number of people affected increases, altering the quality of life to various degrees [1]. In recent years, especially in developed countries, the increase in life expectancy has been observed, but with the prevalence and incidence of diseases of the elderly has also increased. Osteoarthritis has a notable impact on older age groups. Before the age of 50 men have a high prevalence, but the incidence is much more notable in women after 50 years. The risk of gonarthrosis and coxarthrosis increases in women after the initial menopausal period. Osteoarthritis manifests and increases more rapidly in women than in men. It means the fourth morbidity factor in women over 60 years of age and the eighth in men, on a planetary scale [2]. In the past, OA was considered a disease caused by the simple wear and tear of the joint associated with age, leading to loss of cartilage and joint function. It is currently known that $\mathrm{OA}$ is the result of a complex multifactorial process whose result is an alteration of the balance between the processes of destruction and repair of the joint tissues [3]. A determining element in the approach to cases with osteoarthritis is that most of those diagnosed are not subject to appropriate treatment to control the disease, whether due to erroneous selection of drugs, insufficient doses, inappropriate administration, and poor treatment follow-up, wrong diagnoses, lack of rehabilitation and patient information, among others.2 All of the above acts in favor of the decrease in quality of life in older adults who suffer from this disease [2].

Symptoms and signs are usually located only in the affected joints. Pain and stiffness are conceived as the main symptoms. Activity-related pain is intensified by mobilizing the joint after a period of rest [2-4]. May decrease or disappear after mobilization, but returns after extended activity. With rest you can feel the improvement. When suffering in advanced states, the pain appears due to the minimal joint movement and can continue even when resting; it can even affect also at night [2]. Pain and decreased function affect people's ability to carry out their day-to-day activities. Pain itself is an important psychosocial issue related in part to the person's expectations and self-esteem, and is associated with changes in mood and sleep [3]. Passive movement pain and crepitus are understood as two significant signs of the disease. As the disease progresses, signs of instability and deformity also arise due to increased bone and joint size [2]. There is no curative treatment for $\mathrm{OA}$, so the current approach to treatment is symptom management $[3,5]$. However, research is currently being collected in several countries where a new surgical technique is used: fibula 
ostectomy, which seeks pain relief, functional improvement and the ability to assume more intense physical activity than in cases in which a total knee arthroplasty has been chosen.

Therefore, the purpose of this technique is to avoid or delay surgery with more aggressive procedures such as joint replacement. The key to success in ostectomy is the selection of the right patient and the performance of a good surgical technique, taking into account that it is very difficult to predict its evolution [6]. This surgical technique consisting of a proximal fibular ostectomy of approximately 2 centimeters, carried out between 6 and 10 centimeters below the head of the fibula, in order to decompress the internal compartment into the genu painful varus and thus relieve the patient pain, improve patient function and gait with minimal resources and faster recovery, was started by professors Yang Zong-You, Ying Ze Zhang and their group [7,8] of collaborators and has been reproduced in Cuba by Professor Enrique Armando Pancorbo Sandoval and collaborators [6]. In the case of this new surgical technique, the patient is incorporated in less than 24 hours after the surgical act, not requiring support with canes and with full support of the affected limb. No expense is required in osteosynthesis or prosthesis material, which would really make this type of procedure more expensive to improve the quality of life of the patient. Family care problems and complications caused by these types of procedures such as infections, prosthetic breaks or the application of plaster casts are eliminated, being a relief for the patient, the family and society.

Prior to this technique, the high tibial inverted (asymmetric) inverted $\mathrm{V}$ values osteotomy technique was performed, [9] which although it contributed to the clinical improvement of the patient and had fewer complications and adverse effects than knee arthroplasty, it required more time to recovery than the fibula ostectomy technique. Studies are currently being carried out in

ISSN: 2574-1241

DOI: 10.26717/BJSTR.2020.27.004543

Claribel Plain Pazos. Biomed J Sci \& Tech Res

This work is licensed under Creative Commons Attribution 4.0 License

Submission Link: https://biomedres.us/submit-manuscript.php
Cuba on the results of the application of the fibular ostectomy technique in alleviating symptoms and improving the quality of life of patients diagnosed with osteoarthritis of the knee. It is a necessity for the world population that the increase in life expectancy comes together with the quality of life. It is not just about living but about living with quality.

\section{References}

1. Morales C, Pérez E, Galindo A (2019) Osteoartrosis de rodilla Tratamiento con plasma rico en plaquetas. Reporte de 29 casos Revista médica (Colegio de Médicos y Cirujanos de Guatemala) 158(1): 45-46.

2. Viteri Tapia FJ, Muñoz Suárez DA, Rosales Pérez GJ, Hernández Izurieta JP, Jaramillo Villalobos JS, et al. (2019) Osteoartrosis Una revisión de literatura. Rev. Cubana de Reumatol 21(3): 1-11.

3. Choueka MC, Pilonieta CEA, Cortés MED, Sánchez JD, Franco JPF, et al. (2018) Recomendaciones sobre diagnóstico, prevención y tratamiento farmacológico y no farmacológico de la osteoartritis $(\mathrm{OA})$ de rodilla. Revista Colombiana de Medicina Física y Rehabilitación 27(2): 160-184.

4. Solis Cartas Urbano, Calvopiña Bejarano Silvia Johana, Valdés González Elda María (2019) Calidad de vida relacionada con la salud en pacientes con osteoartritis del cantón Riobamba. Rev Cuba Reumatol 21(1): e55.

5. Rojas Vidal Angelo, Valencia Cecilia, Salazar Luis A (2018) Efectividad de la Distracción Tibiofemoral en la Funcionalidad Adicionada al Tratamiento Convencional en Pacientes Mayores de 50 Años con Osteoartritis de Rodilla, Un Estudio Piloto. Int J Morphol 36(1): 267-272.

6. Pancorbo Sandoval Enrique Armando, Ceballos Mesa Alfredo, Martín Tirado Juan Carlos, Quesada Pérez José, Cruz Alard Ronald, et al. (2017) Osteotomía del peroné, nueva técnica quirúrgica en el genu varo doloroso Proceder y presentación de dos casos. Rev Med Electrón 39(4): 966-974.

7. Ying Ze Z (2015) Innovations in Orthopedics and Traumatology in China. Chinese Medical Journal 128(21): 2841-2842.

8. Zong You Yang, Wei Chen, Cun Xiang Li, Juan Wang, De Cheng Shao, et al. Medial Compartment Decompression by Fibular Osteotomy to Treat Medial Compartment Knee Osteoarthritis: A Pilot Study. Orthopedics 38(12): e1110-e1114.

9. Lopez Pereira MA (2010) Osteotomía valguizante en v invertida para la corrección del genuvarum con artrosis unicompartimental de rodilla. In Anales de la Facultad de Ciencias Médicas 43(2): 31-42.

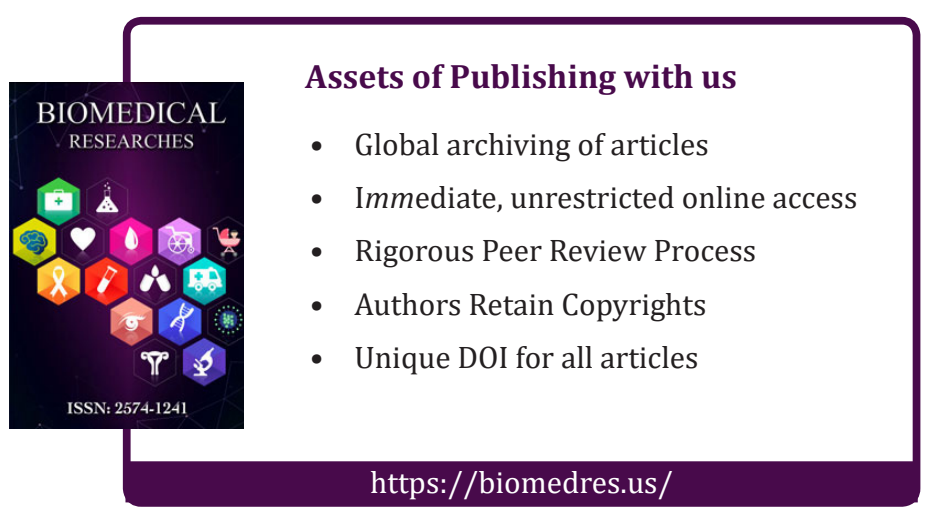

Copyright@ Claribel Plain Pazos | Biomed J Sci \& Tech Res | BJSTR. MS.ID.004543. 